\title{
First observation of unicellular organisms concentrating arsenic in ACC intracellular inclusions
}

Agathe Martignier ${ }^{1}$, Montserrat Filella ${ }^{2 *}$, Jean-Michel Jaquet ${ }^{1}$, Mathieu Coster ${ }^{3}$ and Daniel Ariztegui ${ }^{1}$

${ }^{l}$ Department of Earth Sciences, University of Geneva, Geneva, Switzerland

${ }^{2}$ Department F.-A. Forel, University of Geneva, Geneva, Switzerland

${ }^{3}$ Service de l'écologie de l'Eau, Geneva, Switzerland

* Corresponding author. E-mail address: montserrat.filella@ unige.ch (M. Filella). 


\begin{abstract}
In unicellular organisms, intracellular inclusions of amorphous calcium carbonate (ACC) have been initially described in cyanobacteria and, later, in unicellular eukaryotes of Lake Geneva (Switzerland/France). Inclusions in unicellular eukaryotes -named micropearls- consist of hydrated ACCs, frequently enriched in $\mathrm{Sr}$ or $\mathrm{Ba}$, displaying internal oscillatory zonations due to variations in the $\mathrm{Ba}: \mathrm{Ca}$ or $\mathrm{Sr}: \mathrm{Ca}$ ratios. The analysis of our database consisting of 1597 micropearl analyses from Lake Geneva and 34 from Lake Titicaca (Bolivia/Peru) has shown that a certain number of $\mathrm{Sr}$ and Ba-enriched micropearls from these lakes contain As in amounts measurable by EDXS. A Q-mode statistical analysis has confirmed the existence of five chemically distinct morpho-chemical groups of As-bearing micropearls, among which a new category identified in Lake Geneva, where As is often associated with Mg. This new type of micropearl is possibly produced in a small (7-12 $\mu \mathrm{m}$ size) bi-flagellated organism. Micropearls from Lake Titicaca, which contain $\mathrm{Sr}$, are found in an organism very similar to Tetraselmis cordiformis, observed in Lake Geneva. Lake Titicaca micropearls contain higher As concentrations which can be explained by the high As concentration in the water of this lake. The ubiquity of the biomineralization process observed points to the need for a better understanding of the role of amorphous or crystalline calcium carbonates in As cycling in surface waters.
\end{abstract}

Keywords: Lake Geneva; Lake Titicaca; micropearls; ACC; arsenic; calcium; strontium; barium; biomineralisation; nondetects statistical analysis 


\section{Introduction}

Amorphous calcium carbonate (ACC) is the least stable polymorph of calcium carbonate. Even if chemically unstable, ACC is found naturally in taxa as wide-ranging as sea urchins, corals, molluscs, and foraminifera [1]. Recently, the presence of intracellular inclusions of ACC has been described in cyanobacteria [2,3] and in unicellular eukaryote organisms [4]. The intracellular inclusions of near-amorphous calcium carbonates produced by unicellular eukaryote organisms, and often enriched with other elements such as $\mathrm{Sr}$ and $\mathrm{Ba}$, were named 'micropearls' [4]. Strontium-enriched micropearls were initially found to be produced by an extensively studied phytoplanktonic organism (Tetraselmis cordiformis) in Lake Geneva waters [4] and soon observed to be common among many Tetraselmis species, and potentially in the whole class of Chlorodendrophyceae [5]. The cells of these green algae can contain more than 200 micropearls of approximately $1 \mu \mathrm{m}$ each. Present in multiple regions around the world, such species have been well described by biologists, but micropearls have been overlooked due to their easy dissolution during most biological sample preparation procedures. Micropearls appear translucent in light microscopy but can be observed by using Nomarski differential interference contrast [6]. The function of these mineral inclusions in the organisms remains to be understood. Barium-enriched micropearls (Ba/Ca up to 90) have also been described in Lake Geneva [4]. They are produced by, at least, one organism, but its identification has remained elusive even if Scanning Electron Microscopy (SEM) observation of fixed samples, optical and epifluorescence microscopy, flow cytometry, and metagenomics were applied with identification purposes in more than 25 sampling campaigns along five years. A common characteristic of this biomineralization process in unicellular eukaryotes is the organisms' capacity to strongly concentrate chemical elements from the surrounding water even if present at low or very low concentration levels. Organisms also seem to be element-specific: a given species mainly concentrates a given element (e.g., Sr or Ba) [4,5]. 
All the cations biomineralized in the two previously described micropearl types are alkalineearth elements ( $\mathrm{Ca}, \mathrm{Sr}, \mathrm{Ba}$, with some $\mathrm{Mg}$ often present). The exploration of our extensive collection of filtered water samples from Lake Geneva, containing monthly collected samples since June 2012, has now led to the Energy-Dispersive X-ray Spectroscopy (EDXS) based detection of another element, As, in some specimens of the previously described micropearls and in a new type never described before. From a chemical point of view, the presence of As in micropearls is not surprising since the affinity of $\mathrm{As}^{\mathrm{V}}$ for calcium carbonate is well-known [7]. However, it is remarkable that this biomineralization process has never been described, considering that the toxicity of the element [8-10] has caused it to be widely studied. Numerous As chemical species, such as inorganic (mainly arsenate), methylated (mainly dimethylarsenate), arsenoribosides, and metabolites have been described in unicellular algae $[11,12]$ but, to our knowledge, until Keren et al. [13] described the biomineralization of calcium arsenate by Entotheonella sp., the only other As biogenic mineral described had been orpiment [14].

The treatment of EDXS data for classification purposes, as in this study, is far from straightforward and requires a sound understanding of the analytical signals as well as a rigorous statistical treatment. For this reason, we have paid a particular attention to both aspects and discussed them in detail. The procedure developed here could guide further studies where the treatment of similar data is needed.

\section{Methods}

\subsection{Study area}

A water sampling program has been carried out at the GE3 station $\left(46.2994^{\circ} \mathrm{N} / 6.2197^{\circ} \mathrm{E}\right.$, depth: $70 \mathrm{~m}$ ) in Lake Geneva (Switzerland/France) (Figure SI1) by the SECOE (Service de 
l'écologie de l'Eau) of Canton Geneva since 1995 for water quality monitoring purposes. From June 2012, additional samples have been collected at depths ranging from 0 to $72 \mathrm{~m}$, depending on the situation of the Chl a maximum, to study the particulate matter composition (Table SI1). A few samples taken at station SHL2 $\left(46.452^{\circ} \mathrm{N} / 6.589{ }^{\circ} \mathrm{E}\right.$, depth: $\left.309 \mathrm{~m}\right)$ (Figure SI1), at the deepest part of Lake Geneva, and in Lake Titicaca (Bolivia, Chua 16.19991 ${ }^{\circ} \mathrm{S} / 68.78534{ }^{\circ} \mathrm{W}$, depth: 40m) (Figure SI2) in February 2017, are also included in this study. Altogether, the database consists of 1597 micropearl analyses from Lake Geneva and 34 from Lake Titicaca.

\subsection{Sample preparation}

The sample preparation method consists of a pre-sieving of $250-400 \mathrm{~mL}$ of water (depending on the concentration of organisms present in the water) through a $64 \mu \mathrm{m}$ mesh to eliminate larger grains or organisms, followed by rapid filtration through polycarbonate filters (pore size: $0.2,1,2$ or $5 \mu \mathrm{m}$ ) under less than $10 \mathrm{mb}$ vacuum, making sure that water is completely drained from the filter. The filter is then kept at room temperature in the dark. This method does not preserve the integrity of the cell morphology because the organic matter is altered by drying, but it nevertheless retains some of its characteristics (size and approximate shape of the cell) and allows it to preserve perfectly the micropearls for several years. In order to better understand the morphology of the cells producing micropearls (e.g., presence of flagella), some additional samples have been fixed with glutaraldehyde $(2 \%)$ or alkaline lugol before filtration.

\subsection{SEM-EDSX}

Gold-coated samples ( 10 nm layer) were imaged by a JEOL 7001 FA FEG scanning electron microscope (SEM) equipped with an integrated EDXS detector (JEOL model EX-94300S4L1Q) that provided semiquantitative compositional analyses (accelerating voltage: $15 \mathrm{kV}$ - beam 
current: $7 \mathrm{nA}$ - acquisition time: 30 seconds). The whole energy range (0-20 keV) was acquired and used for element detection.

The following elements were analyzed: $\mathrm{Al}, \mathrm{As}, \mathrm{Ba}, \mathrm{Ca}, \mathrm{Cl}, \mathrm{K}, \mathrm{Mg}, \mathrm{Na}, \mathrm{P}, \mathrm{S}, \mathrm{Si}$, and $\mathrm{Sr}$. The detection level for all the elements measured is estimated at $1 \%$. Analytical results are gathered in an Excel database (SI_excel_1). Results are expressed in mol\% and closed to $100 \%$. This means that the percentages given in this study do not refer to the real composition but are relative to the total concentration of the elements reliably measured in the samples. Caveats involved and choices made concerning EDXS measurements are discussed in detail in Section 4.1.

\subsection{FIB-TEM}

Focused Ion Beam (FIB) preparation of some electron-transparent lamellae (25 $\mu \mathrm{m}$ size) of a micropearl and subsequent analyses by Transmission Electron Microscopy (TEM) were performed at the Interdisciplinary Centre for Electron Microscopy of the EPFL (Lausanne, Switzerland) using a Zeiss NVision 40 CrossBeam instrument (Ga LMIS; $10 \mathrm{keV;} 700$ pA). A FEI Tecnai Osiris TEM with a high brightness XFEG gun, and 4 windowless Super-X SDD detectors allowed the EDXS mapping of As, Ba, C, Ca, and $\mathrm{Sr}$.

\subsection{Arsenic concentrations in lake water}

Arsenic concentrations in Lake Geneva, determined by ICP-MS, are in the range 1.0-1.2 $\mu \mathrm{g}$ $\mathrm{L}^{-1}$. Concentrations were measured by ICP-MS on a Fisons PQ2+ before 2006 and on a ThermoFisher X7 II from 2006 to 2018, both in their standard configurations at by the SECOE (Service de l'écologie de l'Eau) of Canton Geneva, Switzerland. The analytical accuracy was followed by analysing certified reference materials SLRS-4 (before 2010) and SLRS-5 (after 2010) (National Research Council Canada). The analytical laboratory is accredited for the analysis of the trace 
elements in freshwaters (accreditation number: STS245; ISO norm 17025). Profiles show nonconservative behaviour. Reported concentrations of As in Lake Titicaca are higher: $8-15 \mu g \mathrm{~L}^{-1}$ $[15,16]$. Arsenic in Lake Titicaca is mostly of geogenic origin and weakly affected by mining sources.

\subsection{Morpho-chemical classification}

A tentative typology of As-containing micropearls was established based on the presence of the most characteristic chemical elements, the origin of the samples and the visual SEM morphology of the micropearl-bearing cells (observed as clearly defined organic patches, Figures 1, 2 and SI3). The procedure followed is detailed on the flowchart in Figure 3.

\subsection{Data processing}

The sound statistical treatment of the typology preliminary established in 2.6 requires considering the possible presence of element concentration values below their detection limit as well as the existence of non-normal or polymodal distributions. As can be observed in our analytical results database (SI_excel_1, sheet no 1), several elements display a large number of values below the detection level of $1.0 \mathrm{~mol} \%$. Following the strategy proposed by Antweiler [17], we have computed summary statistics and inter-group comparisons on two versions of our data set: the instrument-generated data set, called lab following the terminology in Antweiler and Taylor [18]), and a left-censored data set where all readings below $1.0 \mathrm{~mol} \%$ (hereafter called nondetects, ND) have been replaced by the value $1.0 \mathrm{~mol} \%$.

The statistical analysis of the data in Q-mode proceeded as follows: 
1. Application of criteria for the conservation of descriptors. Some of the elements analysed have a large proportion either of zeros (lab) or ND (left-censored) that must be eliminated to avoid meaningless statistics. Based on [18-20], the criteria for elimination were for lab data: proportion of zero values $>0.6$, and for left-censored data: proportion of ND > 0.7 (Table SI2 and SI_Excel_1, sheet no 1). This procedure led to different sets of descriptors among the various morpho-chemical groups (Tables 1 and 2).

2. Examination of the descriptor distribution. Descriptors were tested for normality by Shapiro-Wilks $W$ criterion at a significance level of $p \geq 0.05$, implemented in the “Univariate/Normality Test" module of the PAST software, v. 4.02 [21] (SI_Excel_1, sheet no 15). To test for $\log$ normality, the $W$ criterion was applied after a log transformation of the descriptors. Bimodality was estimated by visual inspection of the histograms, after an unsuccessful attempt to use the "Model/Mixture analysis" module of PAST (see Table SI3).

3. For the left-censored data, treatment of non-detects according to Helsel [22]. This robust estimation method, between parametric and non-parametric, is based on the regression on order statistics (ROS), implemented in the $R$ environment package called $N A D A$ [19]. It is generally preferred to Maximum Likelihood methods [23] or simple substitution methods [18]. An example of the ROS treatment for MC2 / Cl and Sr descriptors is detailed in SI-excel_2.xlsx.

4. Test of the significance (at the 0.05 significance level) of the differences between the descriptor median values among morpho-chemical groups. Performed with the PAST module "Univariate/Several-Sample tests" using Mann-Witney pairwise $U$ criterion. The 2x2 comparisons are labelled " $\mathrm{D}$ " when the difference is significant, and "S" otherwise (see Table 3 and SI_Excel_1, sheet no 4).

5. Exploratory graphic display of samples in the ternary systems $\mathrm{Mg}-\mathrm{Ca}-\mathrm{As}, \mathrm{As}-\mathrm{Sr}-\mathrm{Ba}$ and $M g-A s-B a$ (Figure 4 and SI_Excel_1, sheet no 26). 


\section{Results}

\subsection{Tentative morpho-chemical classification of arsenic-containing micropearls}

Application of the working scheme in Figure 3 gave a whole dataset consisting of 267 micropearl analyses containing As $>1 \mathrm{~mol} \%$, observed in samples from 28 different campaigns in Lake Geneva between July 2012 and July 2018 (SI_Excel_1, Table SI1) plus 34 micropearls analysed from Lake Titicaca (see database in SI_excel_1). Five morphological groups were identified:

- The presence of $\mathrm{Ba}(\mathrm{n}=66)$ yielded two possibly distinct morpho-chemical groups, MC1 (Big $B a)$ and MC2 (Small Ba). The distinction between MC1 and MC2 is based on cell diameter and $\mathrm{Ba}$ concentration $(20 \mu \mathrm{m}, \mathrm{Ba}<55 \mathrm{~mol} \%$ for $\mathrm{MC} 1 ; 7-10 \mu \mathrm{m}, \mathrm{Ba}>55 \mathrm{~mol} \%$ for $\mathrm{MC} 2)$.

- The presence of Sr yielded MC3 (Lake Geneva) (n=70) and MC4 (Lake Titicaca) (n=34) groups. MC3 corresponds to well-defined, globular cells of $\sim 15 \mu \mathrm{m}$ diameter, which were attributed to Tetraselmis cordiformis in [4] and, thus, will be called Sr-Tetraselmis micropearls here (Figure 4). As-containing micropearls from Lake Titicaca (Sr-Titicaca) show a strong morphological similarity with the MC3 type (Figure 4).

- The remaining As-containing micropearls (n=97) (MC5) often contain Mg and seem produced by a single type unicellular organism with cells of approximately $\sim 9 \mu \mathrm{m}$ diameter. These micropearls, named $M g A s$ (Figure 4 bottom), are small ( $0.7 \mu$ m diameter) and rather difficult to detect in backscattered SEM images due to the relatively low atomic mass of the elements involved. 


\subsection{Lab or left-censored data?}

The descriptors retained for analysis are shown in the data matrices of Tables 1 (lab data) and 2 (left-censored data), after the elimination of those with number of ND exceeding the criteria given in Table SI2. The type of data to be used for further interpretation has been chosen following two criteria:

1. Level of differences between median values in Tables 1 and 2, shown in Table SI3. Differences are small: left-censored data are slightly lower because they have not been closed to 100\% (SI_excel_1/3) with the exception of unreliable values in MC2/Cl due to poor ROS fit (see SI_excel_2.xlsx).

2. Contrasts in the matrices of difference/similarity between morpho-chemical groups (Tables $3 \mathrm{a}$ and $\mathrm{b}$ and their differences in Table SI4). Some discrepancies exist between both datasets for $\mathrm{Na}, \mathrm{Cl}, \mathrm{K}$ and, especially, Mg: globally speaking, significant differences (in pink in Table SI4) or similarities (in green) are more numerous in the lab dataset, suggesting that the ROS transform attenuates the comparison between the groups. This is in accordance with Antweiler's results [17] for group comparisons. For these reasons, further discussion will be restricted to the lab dataset.

\subsection{Statistical confirmation of the typology}

Statistical distributions are heterogeneous across descriptors and groups (Table SI5). They are rarely normal, more often lognormal, and sometimes polymodal. This is why non-parametric methods were used to test for differences between morpho-chemical groups. Table 3A shows the significant differences (D) or similarity $(\mathrm{S})$ in the descriptor median values between morphochemical groups, based on the Mann-Witney $U$ criterion. For a given group and all the descriptors, the index propDg (bottom line of the table) gives the proportion of significant differences or 
statistical separability between a group and all other groups. Separability is excellent for MC1, MC2, and MC5. It is a little lower for MC3 and MC4 because of the similarity between these Srcontaining groups. The role of the various descriptors in the groups' separability can be illustrated by the index propDv (rightmost column in the table). Apart from $\mathrm{K}$, all the descriptors have high discriminating power. The maximum values (1.0) for Ba justifies its role in the initial dichotomy applied in the definition of the morpho-chemical groups. There are also significant differences in As and $\mathrm{Ca}$ concentration between all groups. Finally, $\mathrm{Mg}$ (present in all groups; Table 1) has a weak separating power $(\operatorname{prop} D v=0.7)$ because it presents similar concentrations in MC3 and MC4.

It is interesting to compare the composition of MC3 and MC4 (Figure SI5). There are no significant differences in $\mathrm{Mg}, \mathrm{K}$, and $\mathrm{Sr}$ content. In contrast, the As concentration is much higher in Sr-Titicaca (MC4) (median 11.4 mol\%; Table 1) than in Sr-Tetraselmis (1.9 mol\%), with a reverse contrast in $\mathrm{Ca}(90.8$ vs $69.3 \mathrm{~mol} \%)$. $\mathrm{Na}$ and $\mathrm{Cl}$ are present only in Lake Titicaca.

The global chemical composition of the As micropearls can be summarised in ternary diagrams encompassing their main constituents $(\mathrm{Mg}, \mathrm{Ca}, \mathrm{As}, \mathrm{Sr}$ and $\mathrm{Ba})$ and showing the degree of separability between the morpho-chemical groups (Figure 4). These diagrams are 2-D representations of a five-member space, with the following features confirming the results of Tables 1 and 2: (i) The Big $B a(\mathrm{MC1})$ and Small Ba (MC2) types are optimally separated by their $\mathrm{Ca}$ and Mg content (Table 1; Figures 4 top and bottom). (ii) The Sr-Tetraselmis (MC3) group is separated from the others on the Sr-As axis (Figure 4 middle); this group also has more P, K, and Ca. (iii) The MgAs (MC5) group is also distinct on the Sr-As axis. (iv) The Small Ba, Big Ba, and Sr-Tetraselmis groups match those previously established in [4,5], whereas the $M g A s$ had not been identified previously. Thus, the statistical analysis of the chemical composition of the As-bearing 
micropearls confirmed the initial subdivision into five morpho-chemical groups, with significant differences in their chemical composition.

\subsection{Description of the confirmed categories of As-containing micropearls}

Ba micropearls (MC1 and MC2)

The Big $B a$ group (MC1) is characterized by organic patches of $20-25 \mu \mathrm{m}$ in diameter, with well-defined limits when the sample was fixed (Figures 1a and 2). Barium content in the micropearls varies between 24 and $52 \mathrm{~mol} \%$ and As between 1 and $2.6 \mathrm{~mol} \%$. The organic patches of the Small Ba group (MC2) are smaller $(\sim 7 \mu \mathrm{m})$ and their Ba and As content higher (53-74 mol\% and 1-19 mol \%, respectively (Figure 1a2). The mean Ba and As concentrations are significantly different in both groups, and $\mathrm{Mg}$ reaches a maximum concentration in MC2 (14.2 mol\%). Most of Ba micropearls previously studied [4,5] do not contain As; the present study includes only those containing more than 1 mol\% of As, which represent $13 \%$ of all the Ba-micropearls measured in Lake Geneva (66/515).

Sr micropearls (MC3 and MC4)

The globular shape of the cells producing MC3 micropearls is very characteristic (Figures 1b and 2d). Cells (size: 15-20 $\mu \mathrm{m}$ ) were attributed to Tetraselmis cf. cordiformis, a Chlorodendrophycea microalga, following the results of a study on cultured strains of this genus [5]. Sr-micropearls contain high amounts of $\mathrm{Ca}$ (79-96 mol\%), varying amounts of $\mathrm{Sr}(0-17 \mathrm{~mol} \%)$ with traces of $\mathrm{Mg}, \mathrm{P}$, and $\mathrm{K}$. Arsenic reaches up to 14 mol\% (mean $2.6 \mathrm{~mol} \%$ ). Most of this micropearl type does not contain As: the present statistical analysis includes only those containing more than 1 mol\% of As, which represent but $16 \%$ of all the Sr-micropearls measured in Lake Geneva (138/881). Micropearls containing As may coexist with micropearls containing only Ca 
and Sr within the same cell. MC4 micropearls from Lake Titicaca, and the cell producing them, present a morphology very similar to MC3 micropearls (Figure 2). Compared to MC3, Lake Titicaca micropearls have similar $\mathrm{Mg}$ and $\mathrm{Sr}$ content but are much higher in As and lower in $\mathrm{Ca}$ (As mean 11.1 vs 2.6 mol\%; Figure SI5).

\section{MgAs micropearls (MC5)}

The organic patches containing these micropearls measure approximately $9 \mu \mathrm{m}$ (Figure 2a) and have ill-defined boundaries. In total, 97 micropearls were analysed by EDXS in 44 different cells (Figure 5). Unlike the other groups, the composition of the micropearls produced by these cells nearly always contains As in concentrations above the technique detection limit: $97 \%$ contain As, while only three micropearls in all these unicellular organisms were observed to be composed of $\mathrm{Mg}$ and $\mathrm{Ca}$ only. While the Ca content (mean $85 \mathrm{~mol} \%$, Table 1) varies very little in this group, micropearls within the same cell may have very different As concentrations. In general, the largest micropearls show higher As levels than the smaller ones. Images of a sample fixed with alkaline lugol showed that the organic matter surrounding the MgAs micropearls in the dried samples was a cell with probably two flagella (Figure 5).

\subsection{Localization of As in the Sr-micropearls of Lake Geneva (MC3)}

Thin sections of Sr-rich micropearls (MC3) produced by Tetraselmis and containing As were prepared by FIB, from a sample from Lake Geneva (10 July 2012 at $6 \mathrm{~m}$ ) and mapped by TEMEDXS (Figure 6). Cross-sections show that As, albeit in low concentrations, is concentrated in the outer parts of the micropearls with a thin outermost layer seeming to contain exclusively Ca. Such difference is visible by comparing the As and the Ca EDXS maps of Figure 6. The micropearl on the right-hand side of the mapping in Figure 6 presents a homogeneous content in As because this 
cross-section is only superficial: it does not approach the centre of the micropearl and only the outer layer is mapped. TEM-EDXS analysis performed in the area containing As of the first sample (EDXS arrow in Figure 6) gives $91 \mathrm{~mol} \% \mathrm{Ca}, 6 \mathrm{~mol} \% \mathrm{Sr}, 2 \mathrm{~mol} \%$ As and $1 \mathrm{~mol} \% \mathrm{P}$.

\subsection{The monthly abundance of the MgAs micropearls in Lake Geneva}

Combined with earlier data, samples issued from 20 different campaigns in Lake Geneva, between June 2013 and August 2017 (Table SI1) indicate that the organisms forming these micropearls are most abundant between March and May and are absent from August to January in Lake Geneva (Figure 7). The abundance estimate presented in this figure was achieved by spending the same amount of observation time on each sample previously selected for that specific part of the study. Samples were then classified depending on the number of MgAs micropearls encountered during that limited time $(0=$ none, $1=$ rare, $2-3=$ present, $>4=$ frequent $)$.

\section{Discussion}

\subsection{Analytical procedure}

EDXS provides a suitable tool for the analysis of our samples; the use of alternative techniques such as electron probe microanalysis being excluded because of the requirements of sample preparation (i.e., polished, smooth surface). However, the use of EDXS is not without drawbacks, in particular because the complexity of the phenomena involved in any spectroscopic technique triggered by electron beams makes the accurate quantitative analysis difficult. Indeed, the use of standards is severely limited by proper sets of standards being unavailable while the socalled standardless quantification methods require accessing fundamental and instrumental parameters [24] that makes their application difficult in practice. We have used EDXS in semiquantitative mode because it largely fits our purpose (i.e., spotting the presence of some chemical 
elements in micropearls and the classification of the organisms producing them). Employing semiquantitative EDXS is common practice in similar samples [25]. Since all measurements have been performed by the same operator, using the same apparatus in the same conditions on similar samples (i.e., similar matrix), instrumental parameters, such as the incident angle of the primary beam, are expected to have a similar effect on all chemical elements measured. Matrix effects have been accounted for by ZAF corrections performed with the ZAF-correction software provided by JEOL.

Light elements (atomic number $\mathrm{Z}<11$ ) are not well quantified by EDXS. It is, however, common practice to estimate the percentage composition of light elements from EDXS measurements on the basis of hypotheses made about the chemical identity of the compounds present. Even if this can be done quite confidently for minerals with a known stoichiometry, the method is not trivial for several reasons, namely: (i) the low energy X-rays produced by elements with $\mathrm{Z}$ between 4 and 10 (which includes $\mathrm{C}, \mathrm{N}$ and $\mathrm{O}$ ) are prone to strong absorption by the specimen; (ii) electrons involved in producing the characteristic X-rays of these elements are also involved in their chemical bonding and thus different compounds may influence shapes or position of peaks; (iii) water and natural organic matter bound in mineral structures are not identified by EDXS and will be included in the analysis without distinction; (iv) $\mathrm{C}$ often accumulates as a contaminant on the sample surface in an electron microscope and (v) k-factors of $\mathrm{C}$ are usually not very reliable. When this method is applied to the study of simple, well-defined crystalline carbonates, it is generally more accurate to calculate the quantity of $\mathrm{O}$ (and sometimes $\mathrm{C}$ ) on the base of stoichiometric considerations rather than to measure it, even if this requires knowledge of the valence of the cations, information which is not provided by EDXS. However, in the case of our samples, it is not even possible to apply such a method because: (i) ACC are amorphous and do not have a constant, well-known stoichiometry; (ii) the identity of the As compounds present 
in the samples is unknown and, possibly, variable; (iii) ACC are covered by, and may even include, organic matter of unknown composition but rich in $\mathrm{C}$ and $\mathrm{O}$; (iv) the size of the micropearls is often smaller than the surface area covered by the beam, implying that an undefined and variable amount of organic matter (surrounding the micropearl) is simultaneously 'measured'. For all these reasons, we did not take light elements $(\mathrm{C}, \mathrm{N}$ and $\mathrm{O})$ into account for the elemental quantification of the micropearl composition.

During the EDXS measurements, care was taken to avoid the inclusion of parasitic elements whose presence derives from possible adjacency effects linked to the probe collecting counts in a volume $\left(\sim 2 \mu \mathrm{m}^{3}\right)$ sometimes larger than micropearls. For instance, the $M g A s$ micropearls (MC5) were often surrounded by diatom debris, which would disqualify Si as a true constituent of the micropearls. Sodium (in MC2) and Al (in MC1) are probably parasitic as well, whereas $\mathrm{Na}$ in $\mathrm{MC}$, given the simultaneous presence of $\mathrm{Cl}$, expresses the saline nature of Lake Titicaca (salinity: $\left.0.8 \mathrm{mg} \mathrm{L}^{-1},[26]\right)$.

\subsection{Statistical methodology}

The characteristics of the dataset used in this study require to pay special attention to the applied statistical treatment. In particular, our data are characterised by the presence of rather numerous non-detects or left-censored readings, a common situation in geochemical surveys [20]. Such data should not be merely eliminated, but treated following one of the numerous treatments hitherto applied to left-censored data [17,22,27-29]. The various strategies to deal with leftcensored or below-detection data have been discussed by Antweiler and Taylor [18] in the perspective of computing summary statistics, which is one of the purposes of the present work. Based on their dataset, these authors found that the nonparametric Kaplan-Meier (NP-KM) was the overall best technique for summary statistics, regression on order statistics (ROS) being an 
adequate alternative. Our own dataset having the same cut-off level (1 mol\%) for all the descriptors, NP-KM reduces to a simple substitution by the cut-off value, which would yield strongly biased estimates for all summary statistics (Table 3 in [18]). For comparisons between groups, Antweiler [17] found that instrument-derived data (i.e., our lab data) performed very well relative to other more sophisticated techniques. This is why, essentially, we based our analysis on lab data.

The application of such an approach led to the matrix of descriptors shown in Table 1. Median values, allowing for the non-normal distribution and occasional polymodality of the descriptors, were chosen for the statistical comparison between the morpho-chemical groups. Based on the non-parametric Mann-Whitney $U$ criterion, differences or similarities per descriptor (Table 3) confirmed the initial subdivision of As micropearls into distinct morpho-chemical groups. In particular, all the groups differ significantly in terms of the main constituents, $\mathrm{Ca}$ and As.

No R-mode analysis was undertaken. The nature of our data (closure at 100\%) would imply the application of compositional data analysis concepts [30,31]. These involve, among others, the imputation of non-detects, a delicate and controversial operation [27,32].

\subsection{Arsenic in micropearls}

According to FIB-SEM-EDXS results for Sr-enriched micropearls, As seems to be present, at least in quantities high enough to be detected by EDXS, in the external part of the micropearls. Arsenic presence, either by sorption or precipitation, on ACC is easy to understand based on many studies of As interactions with calcite, both in the laboratory [33-36], in geological [37,38], and environmental settings $[39,40]$. It is, however, not yet possible to explain the difference in As distribution (in external layer) compared with $\mathrm{Sr}$-zoning. It would be tempting to make the 
hypothesis that As does not form a solid solution with $\mathrm{Ca}$, unlike which was suggested for $\mathrm{Ca}-\mathrm{Sr}$ and $\mathrm{Ca}-\mathrm{Ba}$ [41], but this mechanism is controversial for amorphous solids in general [42]. Our observations are, unfortunately, still too limited to allow any sound mechanistic insight in the physico-chemical mechanisms explaining the presence of As in the micropearls.

Low As concentrations and external-only presence point to As being an incidental addition to the micropearls formed by previously described organisms (MC1, MC2, and MC3) and by Lake Titicaca organisms (MC4). Despite the extensive literature on As in algae, only two old studies mention Tetraselmis algae (Tetraselmis chuii, a marine alga) growing in the presence of As $[43,44]$. These authors found that the algae incorporate As rather efficiently and form a lipidsoluble organic As compound.

The present study allowed the discovery of a new category of micropearls, where As is often associated with $\mathrm{Mg}$, possibly in a small unicellular bi-flagellated eukaryote. These micropearls had not been described before, probably because they are much less abundant in Lake Geneva than the previously described types. Moreover, they are challenging to detect due to the small size and fuzzy limits of the organic envelope, and to the fact that, unlike Ba- or Sr-micropearls, the relatively low atomic mass of As does not allow their location easily in backscattered SEM images. Even with fixation, the shape and features of the organism are ill preserved. No clear limit is seen in the dried organic patches, which are the remains of the cells after sample desiccation. We can only state that the cells producing such MgAs-micropearls measure between 7-12 $\mu \mathrm{m}$ and are thus part of the nanoplankton in Lake Geneva, following the size-based classification elaborated by Dussart [45]. In addition, these eukaryotic organisms appear to be biflagellates (Figure 5), and are present in the lake water between February and June (Figure 7). Unfortunately, despite our efforts, data obtained until now do not allow us to confirm the exact nature of this organism. Indeed, 
although nanoplankton includes phytoplankton, some of the smaller ciliates and heterotrophic flagellates, as well as prokaryotes [46], can also enter this size category.

It is not yet possible to predict the importance of this type of biomineralization at the ecosystem level. In the case of groundwaters, the most studied environmental systems in relation to geogenic As contamination -a serious environmental health threat- the most widely accepted mechanism of As release to groundwater is the reduction of iron oxyhydroxides containing a large amount of As, under anoxic conditions [47]. However, since, in general, there is a poor correlation between the concentrations of As and Fe in As-contaminated groundwater [48], the role of calcite has received increased attention as an effective scavenger of As. Arsenic behaviour in eutrophic lakes has also been mostly linked to Fe oxyhydroxides cycling [49-51] but much less studied. The biomineralization process observed here might draw further attention to the role of $\mathrm{Ca}$ in As cycling in surface waters.

\section{Acknowledgements}

We deeply thank Dario Acha and Stephane Guedron for providing the infrastructure and help needed for sampling in Lake Titicaca, data and maps of the sampling location and carefully reading of the manuscript. We thank Pascale Nirel for her help and for insightful discussions. The efficient contribution of the University of Geneva BELS librarians in providing literature references is gratefully acknowledged.

\section{SUPPLEMENTARY MATERIAL}

The Supplementary Material for this article can be found online at: $x x x x$ 


\section{References}

[1] Addadi, L.; Raz, S.; Weiner, S. Taking advantage of disorder: amorphous calcium carbonate and its roles in biomineralization. Adv. Mater. 2003, 15, 959-970. doi:10.1002/adma.200300381

[2] Couradeau, E.; Benzerara, K.; Gérard, E.; Moreira, D.; Bernard, S.; Brown, G.E. Jr; LópezGarcía, P. An early-branching microbialite cyanobacterium forms intracellular carbonates. Science 2012, 336, 459-462. doi:10.1126/science.1216171

[3] Benzerara, K.; Skouri-Panet, F.; Li, J., Férard, C.; Gugger, M.; Laurent, T.; Moreira, D. Intracellular Ca-carbonate biomineralization is widespread in cyanobacteria. PNAS 2014, 111, 10933-10938. doi:10.1073/pnas.1403510111

[4] Martignier, A.; Pacton, M.; Filella, M.; Jaquet, J.-M.; Barja, F.; Pollok, K.; Langenhorst, F.; Lavigne, S.; Guagliardo, P.; Kilburn, M.R.; Thomas, C.; Martini, R.; Ariztegui, D. Intracellular amorphous carbonates uncover a new biomineralization process in eukaryotes. Geobiology 2017, 15, 240-253. doi:10.1111/gbi.12213

[5] Martignier, A.; Filella, M.; Melkonian, M.; Pollok, K.; Bensimon, M.; Barja, F.; Langenhorst, F.; Jaquet, J.-M.; Ariztegui, D. Marine and freshwater micropearls: Biomineralization producing strontium-rich amorphous calcium carbonate inclusions is widespread in the genus Tetraselmis (Chlorophyta). Biogeosciences 2018, 15, 6591-6605. doi:10.5194/bg-15-65912018

[6] Martignier A.; De Respinis, S.; Filella M.; Segovia-Campos, I.; Marin, B.; Günther, G.; Barja, F.; Tonolla, M.; Jaquet, J.-M.; Melkonian, M.; Ariztegui, D. Biomineralization capacities of chlorodendrophyceae: correlation between chloroplast morphology and the distribution of micropearls in the cell. Protist 2020, 171, 125760. doi:10.1016/j.protis.2020.125760

[7] O'Day, P. Chemistry and mineralogy of arsenic. Elements 2006, 2, 77-83. doi:10.2113/gselements.2.2.77.

[8] Neff, J.M. Ecotoxicology of arsenic in the marine environment. Environ. Toxicol. Chem. 1997, 16, 917-927. doi:10.1002/etc.5620160511

[9] Oremland, R. S.; Stolz, J. F. The ecology of arsenic. Science 2003, 300, 939-944. doi:10.1126/science. 1081903 
[10] Ravenscroft, P.; Brammer, H.; Richards, K. Arsenic Pollution: a Global Synthesis. WileyBlackwell, Chichester, 2009.

[11] Duncan, E.G.; Maher, W.A.; Foster, S.D. Contribution of arsenic species in unicellular algae to the cycling of arsenic in marine ecosystems. Environ. Sci. Technol. 2015. 49, 33-50. doi:10.1021/es504074z

[12] Wang, Y.; Wang, S.; Xu, P.; Liu, C.; Liu, M.; Wang, Y.; Wang, C.; Zhang, C.; Ge, Y. Review of arsenic speciation, toxicity and metabolism in microalgae. Rev. Environ. Sci. Bio. 2015, 14, 427-451. doi:10.1007/s11157-015-9371-9

[13] Keren, R.; Mayzel1, B.; Lavy, A.; Polishchuk, I.; Levy, D.; Fakra, S.C.; Pokroy, B.; Ilan, M. Sponge-associated bacteria mineralize arsenic and barium on intracellular vesicles. Nat. Commun. 2016, 8, 14393. doi:10.1038/ncomms 14393

[14] Weiner, S.; Dove, P. M. “An overview of biomineralization processes and the problem of the vital effect" in Biomineralization, eds P. M. Dove, J. J. DeYoreo and S. Weiner, Reviews in Mineralogy and Geochemistry Vol. 54, Mineralogical Society of America, 1-30, 2003.

[15] Archundia, D.; Duwig, C.; Spadini, L.; Uzu., G.; Guédron, S.; Morel, M.C.; Cortez, R.; Ramos Ramos, O.; Chincheros, J.; Martins, J.M.F. How uncontrolled urban expansion increases the contamination of the Titicaca Lake basin (El Alto, La Paz, Bolivia). Water Air Soil Pollut. 2017, 228, 44. doi:10.1007/s11270-016-3217-0

[16] Sarret, G.; Guédron, S.; Acha, D.; Bureau, S.; Arnaud-Godet, F.; Tisserand, D.; Goni-Urriza, M.; Gassie, C.; Duwig, C.; Proux, O.; Aucour, A.-M. Extreme arsenic bioaccumulation factor variability in Lake Titicaca, Bolivia. Sci. Rep. 2019, 9, 10626. doi:10.1038/s41598-01947183-8

[17] Antweiler, R.C. Evaluation of statistical treatments of left-censored environmental data using coincident uncensored data sets. II. Group comparisons. Environ. Sci. Technol. 2015, 49, 13439-13446. doi:10.1021/acs.est.5b02385

[18] Antweiler, R.C.; Taylor, H.T. Evaluation of statistical treatments of left-censored environmental data sets: I. Summary statistics. Environ. Sci. Technol. 2008, 42, 3732-3738. doi:10.1021/es071301c 
[19] Lee, L.; Helsel, D. Statistical analysis of water-quality data containing multiple detection limits: S-language software for regression on order statistics. Computers \& Geosciences $\mathbf{2 0 0 5}$, $31,1241-1248$.

[20] Hites, R.A. Correcting for censored environmental measurements. Environ. Sci. Technol. 2019, 53, 11059-11060. doi:10.1021/acs.est.9b05042

[21] Hammer, Ø.; Harper, D.A.T.; Ryan, P.D. PAST: Paleontological Statistics Software Package for Education and Data Analysis. Palaeontologia Electronica 4(1), 2001, 9 pp. http://folk.uio.no/ohammer/past

[22] Helsel, D.R. Nondetects and Data Analysis. Wiley, New-York, 2005, 250 pp.

[23] Helsel, D.R.; Cohn, T.A. Estimation of descriptive statistics for multiply censored water quality data. Water Resour. Res. 1988, 24, 1997-2004.

[24] Trincavelli, J.; Limandri, S.; Bonetto, R. Standardless quantification methods in electron probe microanalysis. Spectrochim. Acta B 2014, 101, 76-85. doi:10.1016/j.sab.2014.07.016

[25] Scimeca, M.; Bischetti, S.; Lamsira, H. K.; Bonfiglio, R.; Bonanno, E. Energy Dispersive Xray $(\mathrm{EDX})$ microanalysis: A powerful tool in biomedical research and diagnosis. Eur. J. Histochem. 2018, 62, 2841. doi:10.4081/ejh.2018.2841

[26] Acha, D.; Guédron, S.; Amouroux, D.; Point, D.; Lazarro, X.; Fernandez, P.E.; Sarret, G. Algal bloom exacerbates hydrogen sulfide and methylmercury contamination in the emblematic high-altitude Lake Titicaca. Geosciences 2018, 8, 438. doi:10.3390/geosciences 8120438

[27] Helsel, D.R. Fabricating data. How substituting values for nondetects can ruin results, and what can be done about it. Chemosphere 2006, 65, 2434-2439. doi:10.1016/j.chemosphere.2006.04.051

[28] Helsel, D. R. Less than obvious - statistical treatment of data below the detection limit. Environ. Sci. Technol. 1990, 24, 1766-1774. doi:10.1021/es00082a001

[29] Shumway, R.H.; Azar, R.S.; Kayhanian, M. Statistical approaches to estimating mean water quality concentration with detection limits. Environ. Sci. Technol. 2002, 36, 3345-3353. doi:10.1021/es0111129 
[30] van den Boogaart, K.G.; Tolosana-Delgado, R. "Compositions": A unified R package to analyze compositional data. Computers \& Geosciences 2008, 34, 320-338. doi:10.1016/j.cageo.2006.11.017

[31] Reimann, C.; Filzmoser, P.; Hron, K.; Kynčlová, P.; Garrett, R.G. A new method for correlation analysis of compositional (environmental) data - a worked example. Sci. Total Environ. 2017, 607-608, 965-971. doi:10.1016/j.scitotenv.2017.06.063

[32] Palarea-Albaladejo, J.; Martín-Fernández, J.A. Values below detection limit in compositional chemical data. Anal. Chim. Acta 2013, 764, 32-43. doi:10.1016/j.aca.2012.12.029

[33] Román Ross, G.; Cuello, G. J.; Turrillas, X.; Fernández-Martínez, A.; Charlet L. Arsenite sorption and co-precipitation with calcite. Chem. Geol. 2006, 233, 328-336. doi:10.1016/j.chemgeo.2006.04.007

[34] Sø, H. U.; Postma, D.; Jakobsen, R.; Larsen F. Sorption and desorption of arsenate and arsenite on calcite. Geochim. Cosmochim. Acta 2008, 72, 5871-5884. doi:10.1016/j.gca.2008.09.023

[35] Yokoyama, Y.; Tanaka, K.; Takahashi, Y. Differences in the immobilization of arsenite and arsenate by calcite. Geochim. Cosmochim. Acta 2012, 91, 202-219. doi:10.1016/j.gca.2012.05.022

[36] Costagliola, P.; Bardelli, F.; Benvenuti, M.; Di Benedetto, F.; Lattanzi, P.; Romanelli, M.; Paolieri, M.; Rimondi, V.; Vaggelli G. Arsenic-bearing calcite in natural travertines: evidence from sequential extraction, $\mu \mathrm{XAS}$, and $\mu \mathrm{XRF}$. Environ. Sci. Technol. 2013, 47, 6231-6238. doi:10.1021/es304953a

[37] Winkel, L.H.E.; Casentini, B.; Bardelli, F.; Voegelin, A.; Nikolaidis, N. P.; Charlet, L. Speciation of arsenic in Greek travertines: Co-precipitation of arsenate with calcite. Geochim. Cosmochim. Acta 2013, 106, 99-110. doi:10.1016/j.gca.2012.11.049

[38] Alexandratos, V.G.; Elzinga, E.J.; Reeder R. J. Arsenate uptake by calcite: macroscopic and spectroscopic characterization of adsorption and incorporation mechanisms. Geochim. Cosmochim. Acta 2007, 71, 4172-4187. doi:10.1016/j.gca.2007.06.055 
[39] Moon, D.H.; Dermatas, D.; Menounou N. Arsenic immobilization by calcium-arsenic precipitates in lime treated soils. Sci. Total Environ. 2004, 330, 171-185. doi:10.1016/j.scitotenv.2004.03.016

[40] Martínez-Villegas, N.; Briones-Gallardo, R.; Ramos-Leal, J.A.; Avalos-Borja, M.; CastañónSandoval, A.D.; Razo-Flores, E.; Villalobos, M. Arsenic mobility controlled by solid calcium arsenates: A case study in Mexico showcasing a potentially widespread environmental problem. Environ. Poll. 2013, 176, 114-122. doi:10.1016/j.envpol.2012.12.025

[41] Thien, B.; Martignier, A.; Jaquet, J.-M.; Filella, M. Linking environmental observations and solid solution thermodynamic modeling: the case of Ba- and Sr-rich micropearls in Lake Geneva. Pure Appl. Chem. 2017, 89, 645-652. doi:10.1515/pac-2017-0205

[42] Putnis, A. Effects of kinetics and mechanisms of crystal growth on ion-partitioning in solid solution-aqueous solution (SS-AS) systems. European Mineralogical Union Notes in Mineralogy 2010, 10, 43-64. doi:10.1180/EMU-notes.10.2

[43] Irgolic, K.J.; Woolson, E.A.; Stockton, R.A.; Newman, R.D.; Bottino, N.R.; Zingaro, R.A.; Kearney, P.C.; Pyles, R.A.; Maeda, S.; McShane, W.J.; Cox, E.R. Characterization of arsenic compounds formed by Daphnia magna and Tetraselmis chuii from inorganic arsenate. Environ. Health Perspect. 1977, 19, 61-66. doi:10.1289/ehp.771961

[44] Bottino, N.R., Newman, R.D., Cox, E.R., Stockton, R., Hoban, M., Zingaro, R.A., Irgolic, K.J. The effects of arsenate and arsenite on the growth and morphology of the marine unicellular algae Tetraselmis chui (Chlorophyta) and Hymenomonas carterae (Chrysophyta). J. exp. mar. Biol. Ecol. 1978, 33, 153-168. doi:10.1016/0022-0981(78)90005-9

[45] Dussart, B.H. Les différentes catégories de plancton. Hydrobiologia 1965, 26, 72-74.

[46] Lévêque, C. Lake and pond ecosystems. In: Encyclopedia of Biodiversity (second edition). Levin S. (ed.) Academic Press, 458-466, 2001. doi:10.1016/B978-0-12-384719-5.00082-4.

[47] Nickson, R.; McArthur, J.; Burgess, W.; Ahmed, K.M.; Ravenscrofy, P.; Rahman, M. Arsenic poisoning of Bangladesh groundwater. Nature 1998, 395, 338. doi:10.1038/26387

[48] Van Geen, A.; Rose, J.; Thoral, S.; Garnier, J. M.; Zheng, Y.; Bottero, J.Y. Decoupling of As and Fe release to Bangladesh groundwater under reducing conditions. Part II: evidence from 
sediment incubations. Geochim Cosmochim Acta 2004, 68, 3475-3486. doi:10.1016/j.gca.2004.02.014

[49] Aggett, J.; O’Brien, G.A. Detailed model for the mobility of arsenic in lacustrine sediments based on measurements in Lake Ohakuri. Environ. Sci. Technol. 1985, 19, 231-238. doi:10.1021/es00133a002

[50] Kneebone, P.E.; O'Day, P.A.; Jones, N.; Hering, J. G. Deposition and fate of arsenic in ironand arsenic-enriched reservoir sediments. Environ. Sci. Technol. 2002, 36, 381-386. doi:10.1021/es010922h

[51] Couture, R.-M.; Gobeil, C.; Tessier, A. Arsenic, iron and sulfur co-diagenesis in lake sediments. Geochim. Cosmochim. Acta 2010, 74, 1238-1255. doi:10.1016/j.gca.2009.11.028 


\section{Table 1}

Lab data: descriptive statistics of characteristic elements in the five morpho-chemical groups of As-containing micropearls in Lake Geneva (MC1, MC2, MC3 and MC5) and Lake Titicaca (MC4). Ns: number of samples. Nv: number of descriptors. SD: standard deviation. Grey: not taken into consideration because of a proportion of zero values $>0.6$. $\mathrm{P}$ and $\mathrm{S}$ eliminated because they exceed this criterion in all groups.

\begin{tabular}{|c|c|c|c|c|c|c|c|c|c|c|c|c|c|}
\hline Morpho Gr & Ns & $\mathrm{Nv}$ & Stat & $\mathrm{Na}$ & $\mathrm{Mg}$ & $\mathrm{Al}$ & $\mathrm{Si}$ & $\mathrm{Cl}$ & $\mathrm{K}$ & $\mathrm{Ca}$ & As & $\mathrm{Sr}$ & $\mathrm{Ba}$ \\
\hline MC1 & 16 & 6 & Mean & & 0.6 & 0.9 & & & & 58.3 & 1.5 & 1.8 & 37.0 \\
\hline \multirow[t]{2}{*}{$B i g B a$} & & & SD & & 0.7 & 1.2 & & & & 7.0 & 0.4 & 1.2 & 6.6 \\
\hline & & & Median & & 0.3 & 0.6 & & & & 58.5 & 1.3 & 1.8 & 37.4 \\
\hline $\mathrm{MC2}$ & 50 & 6 & Mean & 0.7 & 10.1 & & & 3.0 & & 16.0 & 5.4 & 1.1 & 63.8 \\
\hline \multirow[t]{2}{*}{ Small $B a$} & & & SD & 1.0 & 1.5 & & & 3.6 & & 3.6 & 3.9 & 1.0 & 4.9 \\
\hline & & & Median & 0.1 & 9.9 & & & 0.0 & & 15.9 & 4.6 & 1.2 & 64.5 \\
\hline MC3 & 70 & 5 & Mean & & 0.5 & & & & 1.2 & 90.3 & 2.6 & 5.4 & \\
\hline \multirow[t]{2}{*}{ Sr-Tetraselmis } & & & SD & & 0.6 & & & & 0.9 & 3.5 & 2.3 & 3.3 & \\
\hline & & & Median & & 0.3 & & & & 1.2 & 90.8 & 1.9 & 5.1 & \\
\hline $\mathrm{MC4}$ & 34 & 7 & Mean & 5.9 & 1.3 & & & 8.5 & 1.3 & 66.1 & 11.1 & 5.8 & \\
\hline \multirow[t]{2}{*}{ Sr-Titicaca } & & & SD & 6.8 & 1.9 & & & 6.7 & 1.3 & 13.8 & 3.9 & 3.8 & \\
\hline & & & Median & 4.1 & 0.4 & & & 6.4 & 1.2 & 69.3 & 11.4 & 5.9 & \\
\hline$M C 5$ & 97 & 4 & Mean & & 4.8 & & 2.1 & & & 84.7 & 8.4 & & \\
\hline \multirow[t]{2}{*}{ MgAs } & & & $\mathrm{SD}$ & & 3.7 & & 3.9 & & & 6.1 & 5.8 & & \\
\hline & & & Median & & 5.3 & & 0.4 & & & 85.2 & 7.4 & & \\
\hline
\end{tabular}




\section{Table 2}

Left-censored data: descriptive statistics of characteristic elements in the five morpho-chemical groups of As-containing micropearls in Lake Geneva (MC1, MC2, MC3 and MC5) and Lake Titicaca (MC4). Ns: number of samples. Nv: number of descriptors. SD: standard deviation. Green: ROS-treated. White: Lab values (always above detection limit). Grey: not taken into consideration because of a proportion of zero values exceeding 0.7 . $\mathrm{P}$ and $\mathrm{S}$ eliminated because they exceed this criterion in all groups.

\begin{tabular}{|c|c|c|c|c|c|c|c|c|c|c|c|c|c|}
\hline Morpho Gr & Ns & $\mathrm{Nv}$ & Stat & $\mathrm{Na}$ & $\mathrm{Mg}$ & $\mathrm{Al}$ & $\mathrm{Si}$ & $\mathrm{Cl}$ & $\mathrm{K}$ & $\mathrm{Ca}$ & As & $\mathrm{Sr}$ & $\mathrm{Ba}$ \\
\hline MC1 & 16 & 5 & Mean & & & 0.8 & & & & 57.4 & 1.4 & 1.9 & 36.3 \\
\hline \multirow[t]{2}{*}{$B i g B a$} & & & SD & & & 1.2 & & & & 7.5 & 0.4 & 1.1 & 6.4 \\
\hline & & & Median & & & 0.3 & & & & 57.3 & 1.3 & 1.7 & 36.4 \\
\hline $\mathrm{MC2}$ & 50 & 6 & Mean & & 9.9 & & & 4.1 & & 15.7 & 5.3 & 1.3 & 62.6 \\
\hline \multirow[t]{2}{*}{ Small Ba } & & & SD & & 1.5 & & & 2.8 & & 3.7 & 3.9 & 0.8 & 4.6 \\
\hline & & & Median & & 9.8 & & & 3.0 & & 15.0 & 4.4 & 1.2 & 63.6 \\
\hline $\mathrm{MC3}$ & 70 & 4 & Mean & & & & & & 1.3 & 86.7 & 2.5 & 5.3 & \\
\hline \multirow[t]{2}{*}{ Sr-Tetraselmis } & & & SD & & & & & & 0.6 & 5.6 & 2.3 & 3.1 & \\
\hline & & & Median & & & & & & 1.2 & 88.3 & 1.8 & 4.9 & \\
\hline $\mathrm{MC4}$ & 34 & 7 & Mean & 5.9 & 1.7 & & & 8.5 & 1.4 & 65.8 & 11.1 & 5.7 & \\
\hline \multirow[t]{2}{*}{ Sr-Titicaca } & & & SD & 6.7 & 1.6 & & & 6.6 & 1.1 & 13.8 & 3.9 & 3.6 & \\
\hline & & & Median & 4.1 & 1.2 & & & 6.4 & 1.2 & 69.3 & 11.4 & 5.9 & \\
\hline MC5 & 97 & 4 & Mean & & 5.3 & & 2.3 & & & 82.5 & 8.2 & & \\
\hline \multirow[t]{2}{*}{$M g A s$} & & & SD & & 2.8 & & 3.7 & & & 6.4 & 5.7 & & \\
\hline & & & Median & & 5.1 & & 0.9 & & & 82.8 & 7.3 & & \\
\hline
\end{tabular}


Table 3

Differences (D, pink) or similarity (S, green) in the descriptors medians between morpho-chemical groups, based on Mann-Witney $\mathrm{U}$ criterion ( $\mathrm{p} \geq 0.05$ ). propDv: proportion of differences per descriptor. propDg: proportion of differences per morpho-chemical group. (A): Lab data. (B): leftcensored data.

\begin{tabular}{|c|c|c|c|c|c|c|c|c|c|c|c|c|c|c|c|}
\hline \multicolumn{8}{|c|}{ (A) Lab data } & \multicolumn{8}{|c|}{ (B) Left-censored data } \\
\hline \multirow{6}{*}{$\mathbf{N a}$} & & MC1 & $\mathrm{MC2}$ & $\mathrm{MC3}$ & MC4 & MC5 & $\begin{array}{c}\text { prof } D_{s} \\
1.0\end{array}$ & \multirow{2}{*}{$\mathrm{Na}$} & & $\mathrm{MC1}$ & $\mathrm{MC2}$ & MC3 & MC4 & MC5 & Prophy \\
\hline & $\mathrm{MC1}$ & & & & & & & & $\mathrm{MC1}$ & & & & & & \\
\hline & $\mathrm{MC2}$ & & & & D & & & & $\mathrm{MC2}$ & & & & & & \\
\hline & MC3 & & & & & & & & $\mathrm{MC} 3$ & & & & & & \\
\hline & MC4 & & D & & & & & & $\mathrm{MC4}$ & & & & $x$ & & \\
\hline & MC5 & & & & & & & & MC5 & & & & & & \\
\hline $\mathbf{M g}$ & & $\mathrm{MC1}$ & $\mathrm{MC2}$ & $\mathrm{MC} 3$ & $\mathrm{MC4}$ & MC5 & 0.7 & $\mathbf{M g}$ & & $\mathrm{MC1}$ & $\mathrm{MC2}$ & $\mathrm{MC} 3$ & $\mathrm{MC4}$ & MC5 & 1.0 \\
\hline & $\mathrm{MC1}$ & & $D$ & $\mathrm{~s}$ & $\mathrm{~s}$ & D & & & MC1 & & & & & & \\
\hline & $\mathrm{MC2}$ & D & & D & D & D & & & $\mathrm{MC2}$ & & & & D & $D$ & \\
\hline & MC3 & $\mathrm{s}$ & D & & s & D & & & MC3 & & & & & & \\
\hline & MC4 & s & D & s & & D & & & MC4 & & D & & & D & \\
\hline & MC5 & D & D & D & D & & & & MC5 & & D & & D & & \\
\hline Al & & $\mathrm{MC1}$ & $\mathrm{MC2}$ & $\mathrm{MC3}$ & MC4 & MC5 & 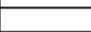 & Al & & $\mathrm{MC1}$ & $\mathrm{MC2}$ & $\mathrm{MC} 3$ & MC4 & MC5 & \\
\hline & $\mathrm{MC1}$ & $x$ & & & & & & & MC1 & & & & & & \\
\hline & $\mathrm{MC2}$ & & & & & & & & $\mathrm{MC2} 2$ & & & & & & \\
\hline & MC3 & & & & & & & & $\mathrm{MC3}$ & & & & & & \\
\hline & MC4 & & & & & & & & MC4 & & & & & & \\
\hline & MC5 & & & & & & & & MC5 & & & & & & \\
\hline $\mathrm{Si}$ & & $\mathrm{MC1}$ & $\mathrm{MC2}$ & $\mathrm{MC3}$ & $\mathrm{MC4}$ & MC5 & & $\mathrm{Si}$ & & $\mathrm{MC1}$ & $\mathrm{MC2}$ & $\mathrm{MC3}$ & $\mathrm{MC4}$ & MC5 & \\
\hline & $\mathrm{MC1}$ & & & & & & & & MC1 & & & & & & \\
\hline & $\mathrm{MC2}$ & & & & & & & & $\mathrm{MC2}$ & & & & & & \\
\hline & MC3 & & & & & & & & MC3 & & & & & & \\
\hline & MC4 & & & & & & & & MC4 & & & & & & \\
\hline & MC5 & & & & & $x$ & & & MC5 & & & & & $x$ & \\
\hline $\mathrm{Cl}$ & & $\mathrm{MC1}$ & $\mathrm{MC2}$ & $\mathrm{MC} 3$ & $\mathrm{MC4}$ & MC5 & 1.0 & CI & & $\mathrm{MC1}$ & $\mathrm{MC2}$ & $\mathrm{MC} 3$ & $\mathrm{MC4}$ & MC5 & 1.0 \\
\hline & $\mathrm{MC1}$ & & & & & & & & $\mathrm{MC1}$ & & & & & & \\
\hline & $\mathrm{MC2}$ & & & & $\mathbf{D}$ & & & & $\mathrm{MC2}$ & & $x$ & & & D & \\
\hline & MC3 & & & & & & & & $\mathrm{MC} 3$ & & & & & & \\
\hline & MC4 & & $D$ & & & & & & MC4 & & & & $x$ & & \\
\hline & MC5 & & & & & & & & MC5 & & $\mathbf{D}$ & & & & \\
\hline $\mathbf{K}$ & & $\mathrm{MC1}$ & $\mathrm{MC2}$ & $\mathrm{MC} 3$ & $\mathrm{MC4}$ & MC5 & 0.0 & K & & $\mathrm{MC1}$ & $\mathrm{MC2}$ & $\mathrm{MC3}$ & MC4 & MC5 & 0.0 \\
\hline & $\mathrm{MC1}$ & & & & & & & & $\mathrm{MC1}$ & & & & & & \\
\hline & $\mathrm{MC2}$ & & & & & & & & $\mathrm{MC2}$ & & & & & & \\
\hline & MC3 & & & & s & & & & MC3 & & & & & $s$ & \\
\hline & MC4 & & & s & & & & & MC4 & & & & & & \\
\hline & MC5 & & & & & & & & MC5 & & & $s$ & & & \\
\hline $\mathrm{Ca}$ & & $\mathrm{MC1}$ & $\mathrm{MC2}$ & $\mathrm{MC} 3$ & $\mathrm{MC4}$ & MC5 & 1.0 & $\mathrm{Ca}$ & & $\mathrm{MC1}$ & $\mathrm{MC2}$ & $\mathrm{MC} 3$ & $\mathrm{MC4}$ & MC5 & 1.0 \\
\hline & $\mathrm{MC1}$ & & D & D & D & D & & & MC1 & & D & D & D & D & \\
\hline & $\mathrm{MC2}$ & D & & D & D & D & & & MC2 & D & & D & D & D & \\
\hline & MC3 & D & D & & D & D & & & $\mathrm{MC} 3$ & D & D & & D & D & \\
\hline & MC4 & D & D & D & & D & & & $\mathrm{MC4}$ & D & D & D & & D & \\
\hline & MC5 & D & D & D & $\mathbf{D}$ & & & & MC5 & $\mathbf{D}$ & D & D & D & & \\
\hline$A_{s}$ & & $\mathrm{MC1}$ & $\mathrm{MC2}$ & $\frac{\mathrm{D}}{\mathrm{MC} 3}$ & $\frac{\mathrm{M}}{\mathrm{MC4}}$ & MC5 & 1.0 & As & & $\mathrm{MC1}$ & $\mathrm{MC2}$ & $\mathrm{MC3}$ & MC4 & MC5 & 1.0 \\
\hline & $\mathrm{MC1}$ & & $D$ & D & D & D & & & $\mathrm{MC1}$ & & D & D & D & D & \\
\hline & $\mathrm{MC2}$ & D & & $D$ & D & D & & & $\mathrm{MC2}$ & D & & D & D & $D$ & \\
\hline & $\mathrm{MC} 3$ & D & D & & D & D & & & $\mathrm{MC} 3$ & D & D & & D & D & \\
\hline & MC4 & D & D & D & & D & & & MC4 & D & D & D & & D & \\
\hline & MC5 & D & $D$ & $\mathrm{D}$ & $\mathbf{D}$ & & & & MC5 & $\mathbf{D}$ & D & D & D & & \\
\hline $\mathrm{Sr}$ & & $\mathrm{MC1}$ & $\mathbf{M}$ & $\mathrm{MC} 3$ & $\frac{\mathrm{M}}{\mathrm{M} 4}$ & MC5 & 0.8 & $\mathrm{Sr}$ & & $\mathrm{MC1}$ & $\mathrm{MC2}$ & $\mathrm{MC} 3$ & MC4 & MC5 & 0.8 \\
\hline Jr & $\mathrm{MC1}$ & MALI & $\mathbf{D}$ & D & MOA & FILS & 0.8 & & MC1 & & D & D & D & & \\
\hline & $\mathrm{MC2}$ & D & & $\mathrm{D}$ & $\mathbf{D}$ & & & & $\mathrm{MC2}$ & D & & D & D & & \\
\hline & $\mathrm{MC} 3$ & D & D & & $\frac{\mathrm{v}}{\mathrm{S}}$ & & & & $\mathrm{MC} 3$ & D & D & & s & & \\
\hline & MC4 & D & D & s & & & & & MC4 & D & D & s & & & \\
\hline & MC5 & & & & & & & & MC5 & & & & & & \\
\hline & & $\mathrm{MC1}$ & $\mathrm{MC2}$ & $\mathrm{MC} 3$ & $\mathrm{MC4}$ & MC5 & 1.0 & $\mathrm{Ba}$ & & $\mathrm{MC1}$ & $\mathrm{MC2}$ & $\mathrm{MC3}$ & $\mathrm{MC4}$ & MC5 & 1.0 \\
\hline & $\mathrm{MC1}$ & & $D$ & & $\mathrm{Mat}_{4}$ & & & & $\mathrm{MC1}$ & & D & & & & \\
\hline & $\mathrm{MC2}$ & D & & & & & & & $\mathrm{MC2} 2$ & D & & & & & \\
\hline & $\mathrm{MC} 3$ & & & & & & & & $\mathrm{MC} 3$ & & & & & & \\
\hline & MC4 & & & & & & & & $\mathrm{MC4}$ & & & & & & \\
\hline & MC5 & & & & & & & & MC5 & & & & & & \\
\hline & Prop & 0.88 & 1.00 & 0.75 & 0.78 & 1.00 & & & PropDg & 1.00 & 1.00 & 0.83 & 0.92 & 0.92 & \\
\hline
\end{tabular}




\section{FIGURE 1}

Specimens of the four types of micropearls incorporating As in Lake Geneva. All are secondaryelectron SEM images of dried filters except a1: backscattered SEM image of a dried sample fixed with glutaraldehyde. Micropearls appear white or light grey against the darker organic matter. Elements linked to sample coating were not taken into account in the calculations: $\mathrm{Au}((\mathrm{a})$ and (c)) and $\mathrm{Pt} / \mathrm{Pd}(\mathrm{b})$. Whole spectra of samples are shown in Figure SI4. Pores of the filters appear as small black dots. Water samples were taken in Lake Geneva at GE3 location on (a1) 10.07.2018, cumulative sample between 0 and $50 \mathrm{~m}$, (a2) 14.06. 2016, $10 \mathrm{~m}$, (b) 06.08.2013, $10 \mathrm{~m}$ depth, (c) 19.05.2015, $18 \mathrm{~m}$. d: diatom frustule fragments. OM and yellow dotted lines: unrelated organic matter. Scale bars: $5 \mu \mathrm{m}$.
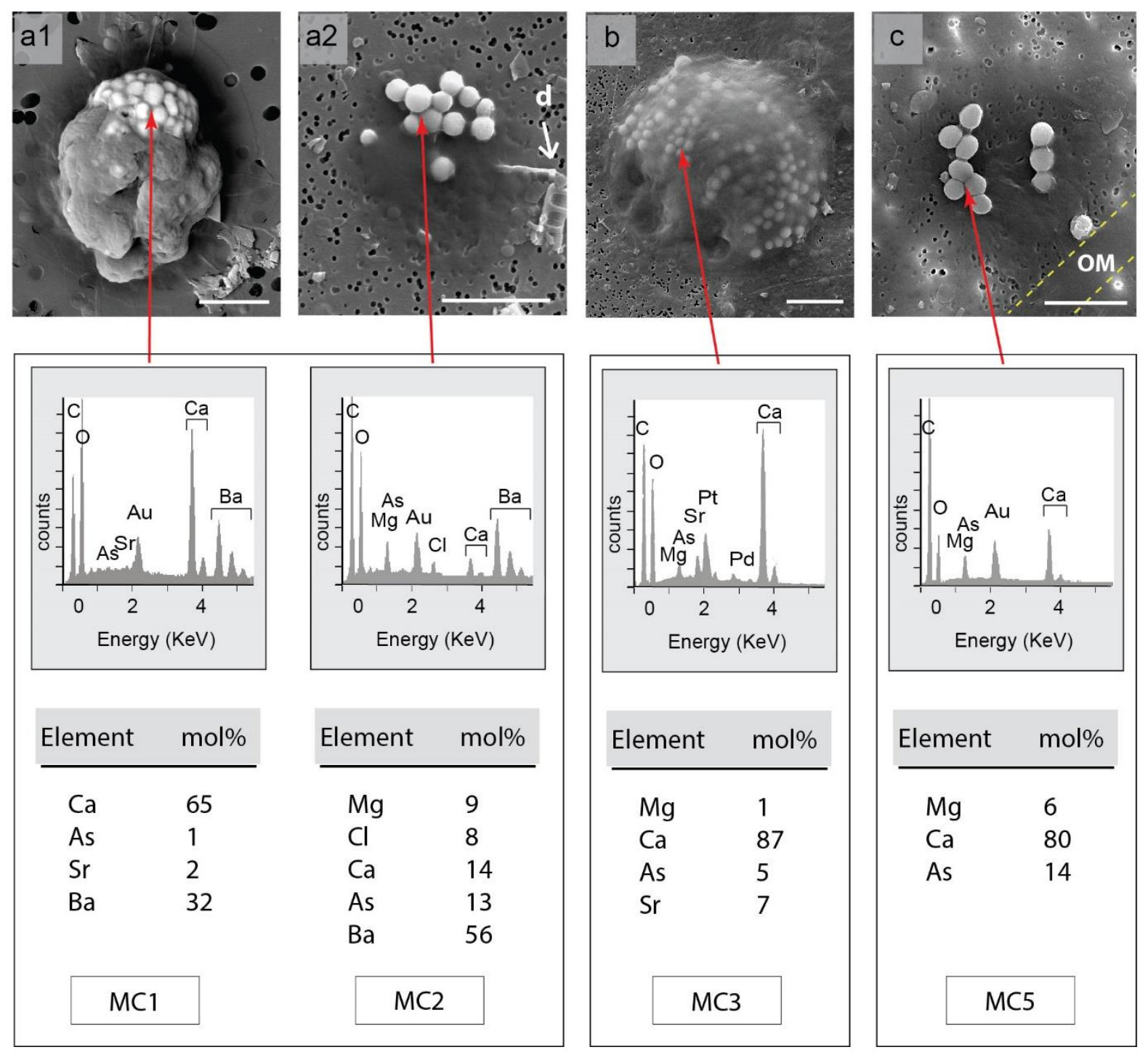


\section{FIGURE 2}

Micropearls observed in Lake Titicaca (Sr-Titicaca / MC4), compared to Sr-Tetraselmis micropearls of Lake Geneva (MC3). SEM images of dried filters. (a), (b), (d): backscattered electron images. (c): secondary electron image. (a) to (c): Water sample taken in Lake Titicaca in February 2017. (a) and (b) Sr-Titicaca micropearls, clustered inside the organic cell which produced them. The SEM-EDXS spectrum illustrates the typical composition of these micropearls. Presence of gold is due to sample coating. (c): Zoom on Sr-Titicaca micropearls, expelled from a cell during filtration. (d): For comparison, Tetraselmis cordiformis cell, from Lake Geneva, with its Sr-rich micropearls (MC3). Sampled at the GE3 location (6.08.2013, 20 $\mathrm{m}$ depth). The larger and slightly darker inclusions are polyphosphate inclusions (p), which are sometimes present in these unicellular algae. The small black dots in the background are the pores of the filter. d: diatom. s: silica. Thick scale bar: $1 \mu \mathrm{m}$. Thin scale bar: $5 \mu \mathrm{m}$.
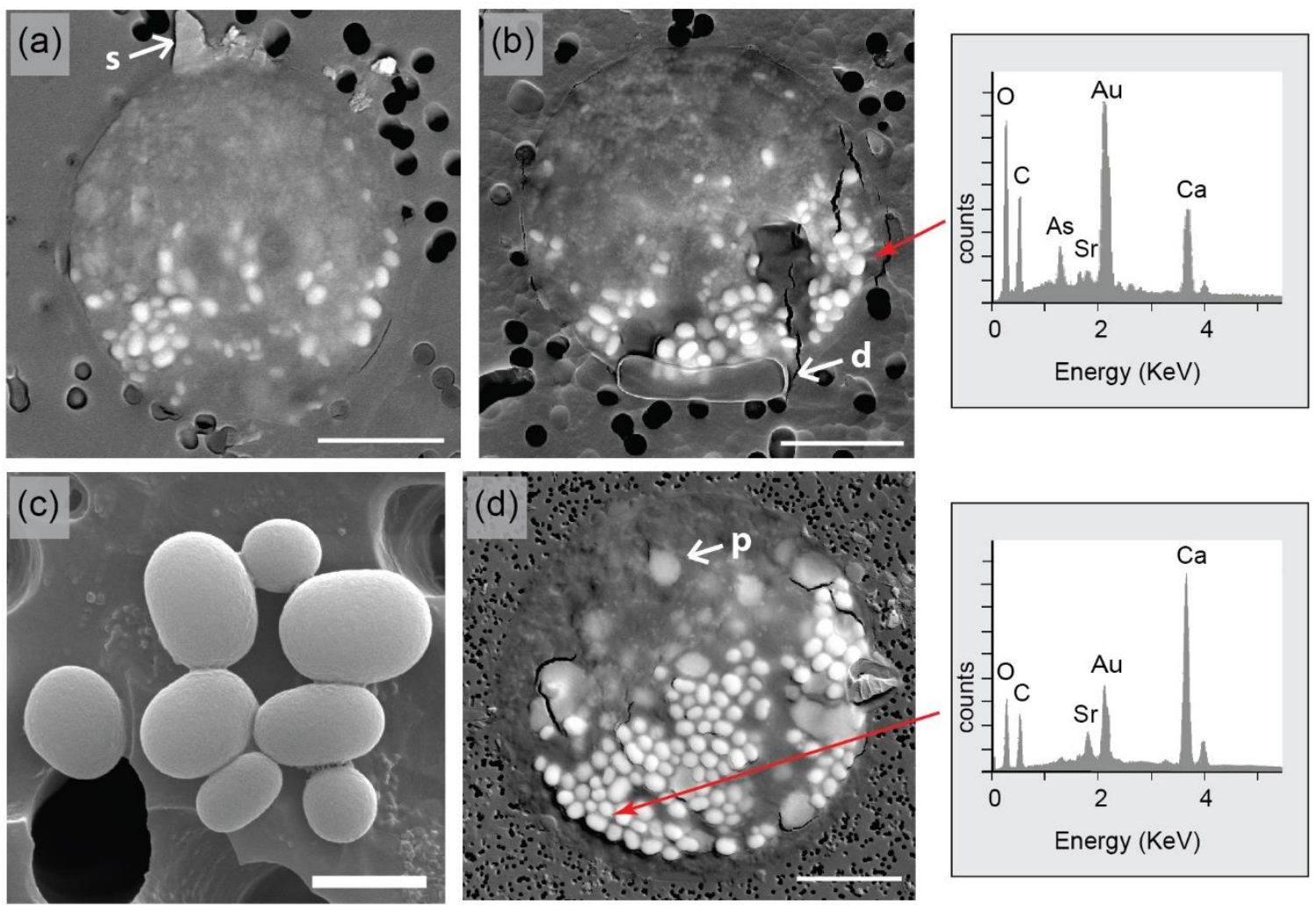


\section{FIGURE 3}

Procedure for the definition of five morpho-chemical groups among the As-bearing micropearls in Lakes Geneva and Titicaca.

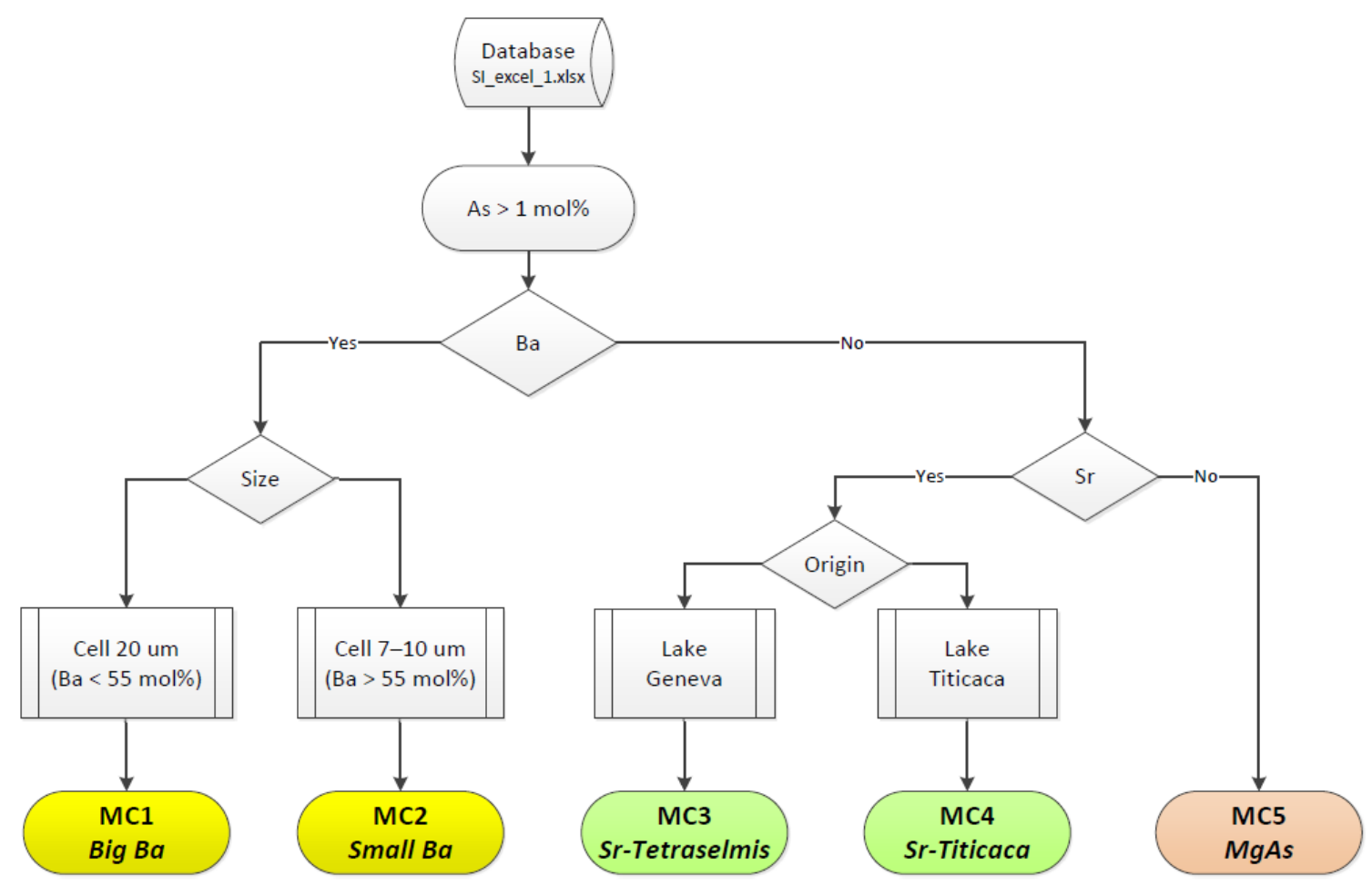




\section{FIGURE 4}

Mg-Ca-As, Mg-Ba-As and Sr-Ba-As ternary representation of micropearls containing As and their morpho-chemical groups.

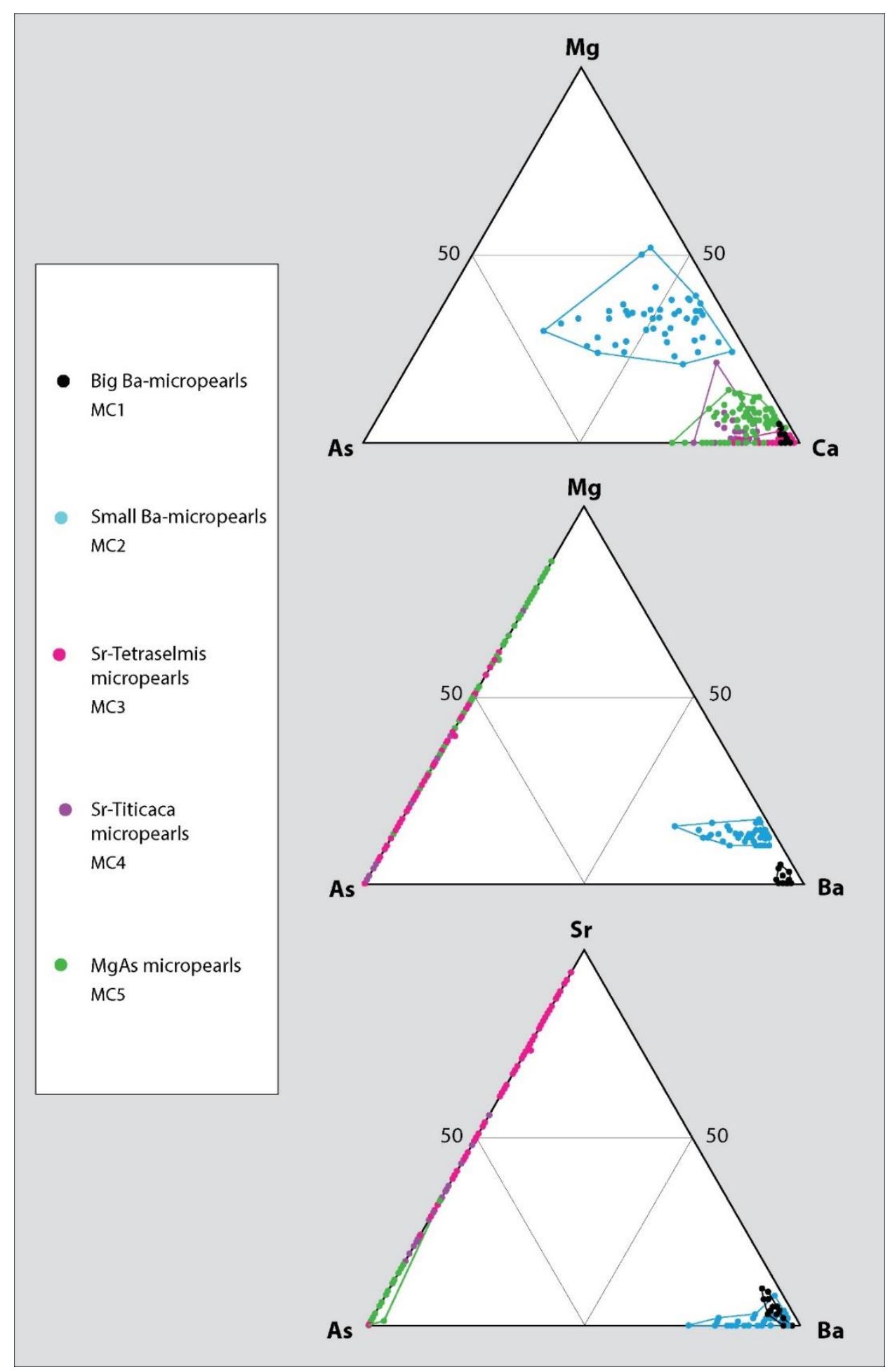




\section{FIGURE 5}

Morphology of the organic matter surrounding the $M g A s$ micropearls (MC5). Secondary-electron SEM image of a dried filter. Sample (a) was filtered and dried while sample a1 shows the raw image while a 2 shows an approximate delimitation of the dried cell in which the micropearls were formed; (b) was fixed with alkaline lugol before filtration; therefore the organism is better preserved, allowing the observation of two flagella (detail shown on image b2). Pores of the filter $(0.2 \mu \mathrm{m})$ appear as small black dots. Water samples taken in Lake Geneva at (a) SHL2 location, $10 \mathrm{~m}$ depth, 11.05.2015, (b) GE3 location, $10 \mathrm{~m}$ depth, 21.04.2016. d: diatom. Scale bar: $5 \mu \mathrm{m}$.
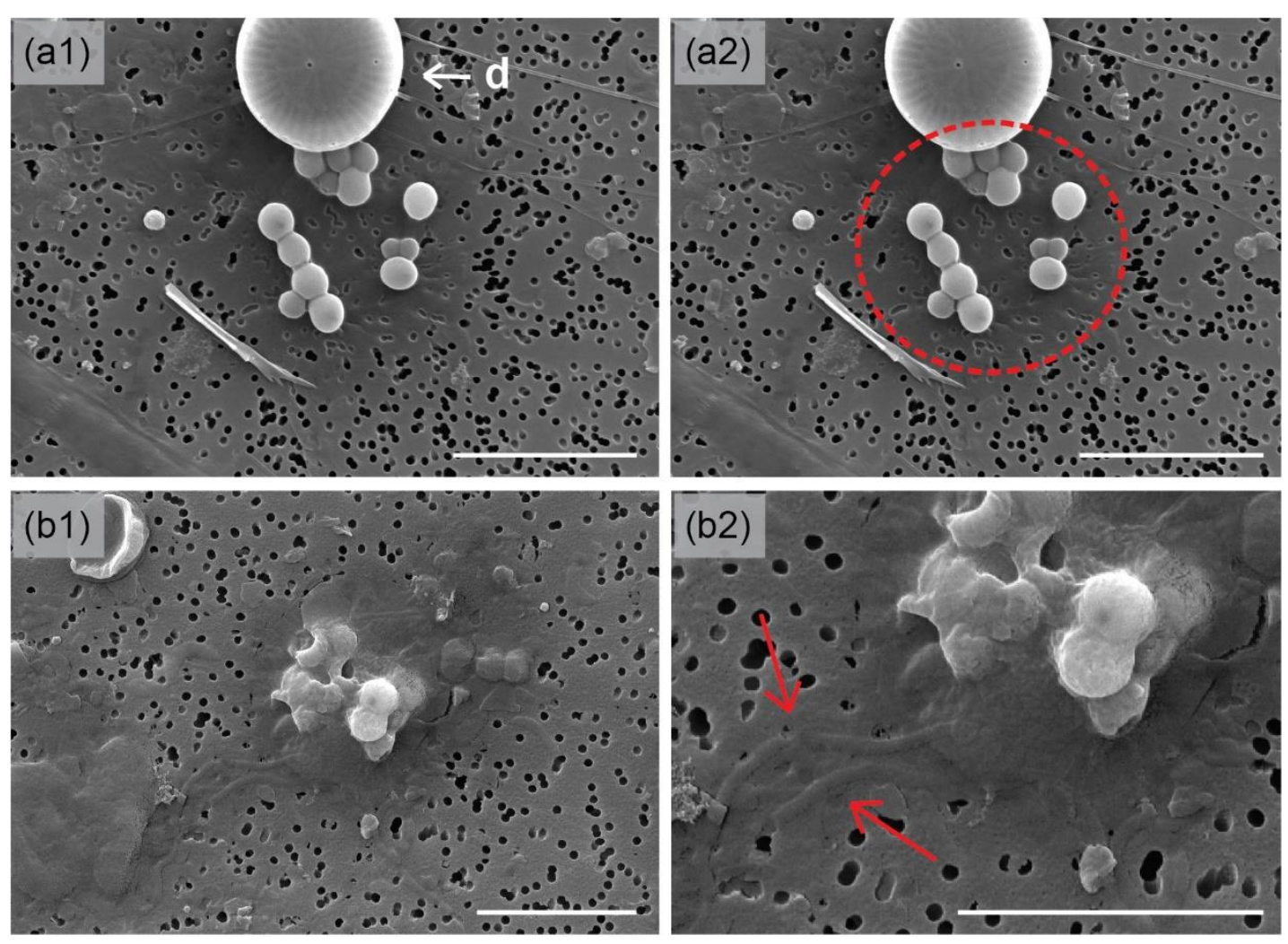


\section{FIGURE 6}

STEM-HAADF images and EDXS maps from FIB-cuts of a Sr-Tetraselmis micropearl (MC3) sample showing the location of As. The water sample was taken on 10.07.2012, at $6 \mathrm{~m}$ depth. Arsenic is concentrated in the external layers of the micropearls. Note that the Pt protection layer on top of the samples (from FIB preparation) also produces an X-ray line at the energy window used for As, inducing it to be included in the As mapping. The position of the FIB-cut is marked by a red line on in the inset SEM image.

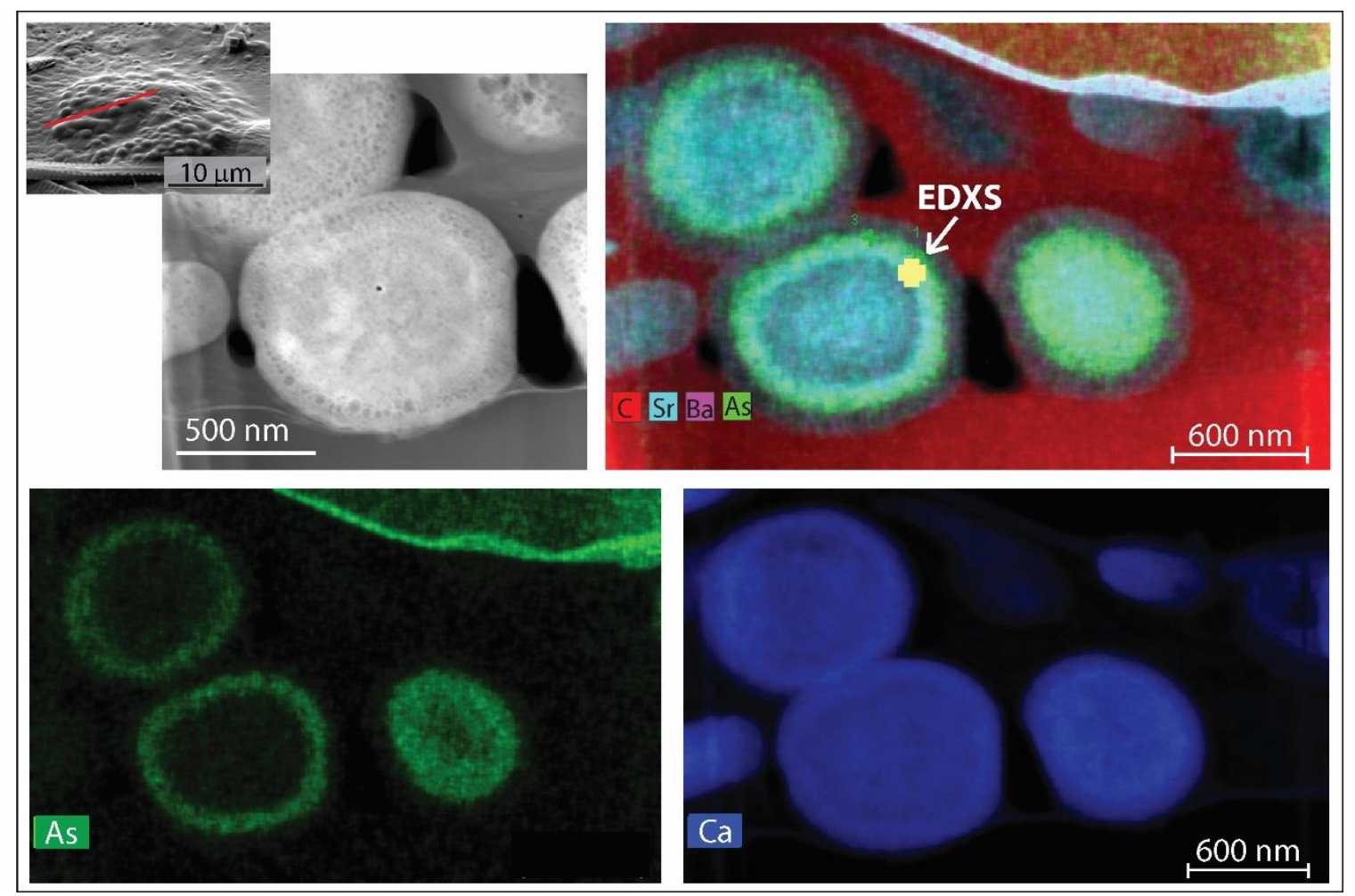




\section{FIGURE 7}

Estimation of the monthly abundance of the $M g A s$ micropearls (MC5) in Lake Geneva. Organisms forming this type of micropearls are observed between February and July.

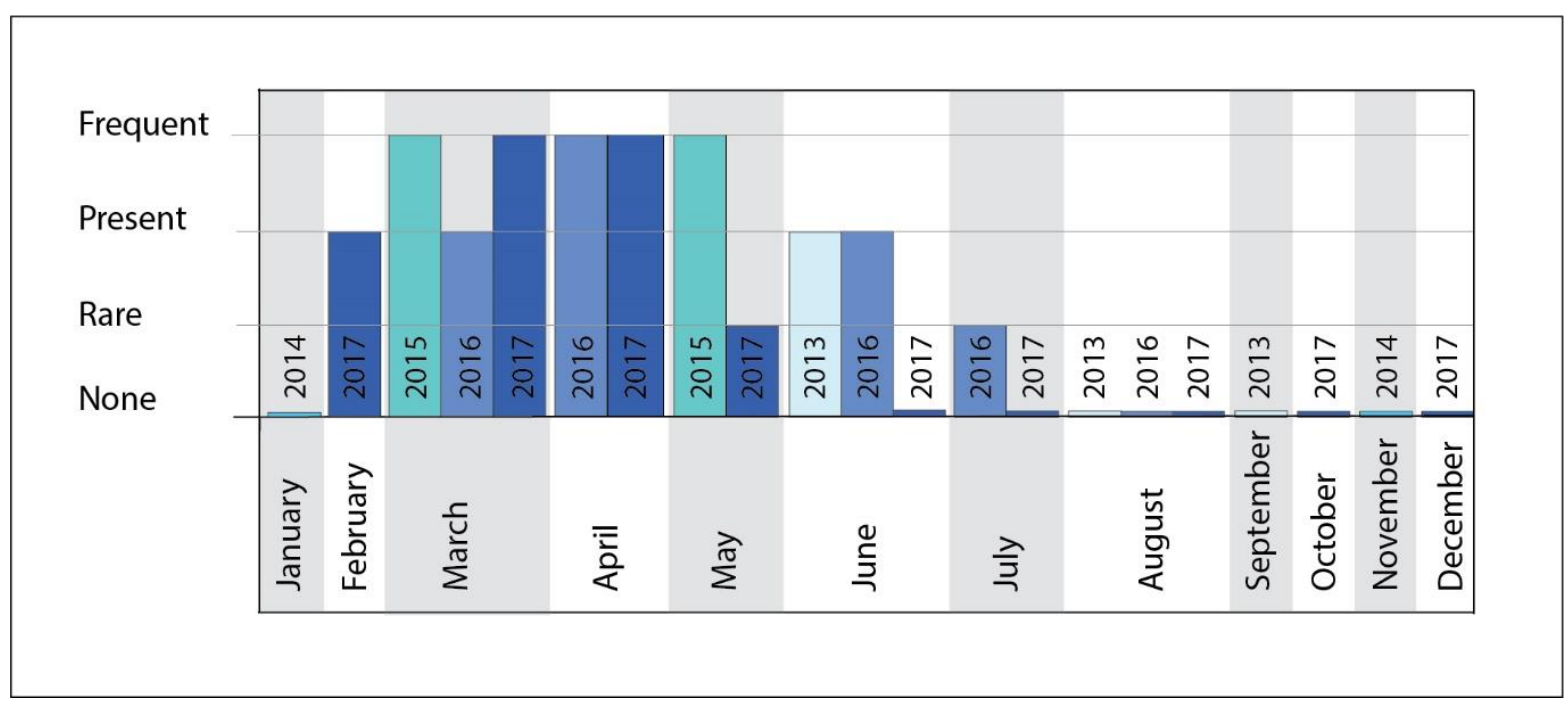

